\title{
Emissions of an agricultural engine using blends of diesel and hydrous ethanol
}

\section{Emissões de motor agrícola utilizando misturas de óleo Diesel e etanol hidratado}

\author{
Marcelo Silveira de Farias ${ }^{1 *}$; José Fernando Schlosser²; Javier Solis Estrada ${ }^{3}$; \\ Gismael Francisco Perin ${ }^{4}$; Alfran Tellechea Martini ${ }^{5}$
}

\begin{abstract}
The growing global demand of energy, the decrease of petroleum reserves and the current of environmental contamination problems, make it imperative to study renewable energy sources for use in internal combustion engines, in order to decrease the dependence on fossil fuels and reduce emissions of pollutant gases. This study aimed to evaluate the emissions of a diesel-cycle engine of an agricultural tractor that uses diesel S500 (B5) mixed with 3, 6, 9, 12 and 15\% of hydrous ethanol. It determined emissions of $\mathrm{CO}_{2}(\mathrm{ppm}), \mathrm{NO}_{\mathrm{x}}(\mathrm{ppm})$, and opacity ( $\mathrm{k}$ value) of gases. A standard procedure was applied considering eight operating modes (M1, M2, M3, M4, M5, M6, M7, and M8) by breaking with an electric dynamometer in a laboratory. The experimental design was completely randomized, with 60 replicates and a $6 \times 8$ factorial design. Greater opacity and gas emissions were observed when the engine operated with $3 \%$ ethanol, while lower emissions occurred with 12 and $15 \%$. With these fuels, the reduction of opacity, $\mathrm{CO}_{2}$, and $\mathrm{NO}_{x}$, in relation to diesel oil, was 24.49 and $26.53 \%, 4.96$ and $5.15 \%$, and 6.59 and $9.70 \%$, respectively. In conclusion, the addition of 12 and $15 \%$ ethanol in diesel oil significantly reduces engine emissions.
\end{abstract}

Key words: Alternative fuels. $\mathrm{CO}_{2}$ emission. Diesel-cycle. Pollutants.

\section{Resumo}

A crescente demanda mundial por energia, a diminuição das reservas de petróleo e os atuais problemas de poluição ambiental, instigam o estudo de fontes renováveis de energia para utilização nos motores de combustão interna, visando à diminuição da dependência do combustível fóssil e redução das emissões de gases poluentes. Este trabalho teve por objetivo avaliar as emissões de um motor ciclo Diesel de um trator agrícola utilizando óleo Diesel S500 (B5) e, em mistura com 3, 6, 9, 12 e 15\% de etanol hidratado. As variáveis avaliadas foram as emissões de $\mathrm{CO}_{2}(\mathrm{ppm}), \mathrm{NO}_{\mathrm{x}}(\mathrm{ppm})$ e a opacidade (valor k) dos gases. Para a avaliação utilizou-se procedimento normalizado, com aplicação de oito modos de operação (M1; M2; M3; M4; M5; M6; M7 e M8), por meio da frenagem com um dinamômetro elétrico, em laboratório. O delineamento experimental foi inteiramente casualizado, com 60 repetições e no esquema fatorial 6x8. Os maiores valores de opacidade e emissões de $\mathrm{CO}_{2}$ e $\mathrm{NO}_{\mathrm{x}}$ foram alcançados

\footnotetext{
${ }^{1}$ Eng $^{\circ}$ Agr $^{\circ}$, Prof. Dr. Adjunto, Universidade Federal de Santa Maria, UFSM, Campus Frederico Westphalen, Frederico Westphalen, RS, Brasil. E-mail: silveira farias@hotmail.com

2 Eng $^{\circ}$ Agr ${ }^{\circ}$, Prof. Dr. Titular, UFSM, Santa Maria, RS, Brasil. E-mail: josefernandoschlosser@gmail.com

3 Eng $^{\circ}$ Agrícola, Distribuidor Oficial John Deere, IPESA S.A.C, Lima, Peru. E-mail: j.solis.estrada@gmail.com

4 Eng $^{\text {O }}$ Agr $^{\mathrm{O}}$, Prof. Adjunto, Universidade Federal da Fronteira Sul, UFFS, Campus Erechim, Erechim, RS, Brasil. E-mail: gismaelperin@gmail.com

5 Eng $^{\text {o }}$ Agr $^{\circ}$, Prof. Substituto, UFSM, Campus Cachoeira do Sul, Cachoeira do Sul, RS, Brasil. E-mail: alfrantm@gmail.com

* Author for correspondence
} 
com $3 \%$ de etanol, enquanto que os menores valores foram obtidos quando o motor utilizou 12 e $15 \%$. Com estes combustíveis, a redução da opacidade, $\mathrm{CO}_{2}$ e $\mathrm{NO}_{x}$, em relação ao óleo diesel, foi de 24,49 e $26,53 \% ; 4,96$ e 5,15\% e 6,59 e 9,70\%, respectivamente. Conclui-se que, a adição de 12 e $15 \%$ de etanol no óleo diesel reduz significativamente as emissões do motor.

Palavras-chave: Ciclo Diesel. Combustíveis alternativos. Emissão de $\mathrm{CO}_{2}$. Poluentes.

\section{Introduction}

At the end of the twentieth century, environmental contamination problems associated with the combustion of fossil fuels became evident, and this could be considered a global crisis (AGEJAS, 1996). According to the author, the biosphere was put at risk due to an imbalance in the ecosystem caused by the way humans interact with the world.

The major imbalance, a product of the combustion of oil derivatives, occurs in the carbon dioxide cycle $\left(\mathrm{CO}_{2}\right)$, large quantities of which contribute to global warming (GIAKOUMIS et al., 2013). Nitrogen oxides $\left(\mathrm{NO}_{\mathrm{x}}\right)$, sulfur $\left(\mathrm{SO}_{\mathrm{x}}\right)$, and particulate matter (PM) emitted after combustion contribute to the formation of acid rain and the destruction of the ozone layer (KIM et al., 2017; RESITOGLU; KESKIN, 2017).

Moreover, these emissions cause human health problems and have effects on long-term illnesses, with risk of cancer (TADANO et al., 2014). In the short term, $\mathrm{CO}_{2}$ emissions in large quantities are fatal to humans (MANZETTI; ANDERSEN, 2016), while $\mathrm{NO}_{\mathrm{x}}$ emissions are associated with respiratory diseases, and PM is related to eye irritation and coughing (LEVY, 2015).

In this context, considering the global increase in energy demand, the scarcity of oil reserves, the concern for climate change, and new environmental regulations, researchers are increasingly interested in examining the use of alternative fuels for internal combustion engines (AL-HASSAN et al., 2012).

Using ethanol as a biofuel contributes to significant reduction in engine gas emissions (GENG et al., 2017; MOFIJUR et al., 2015). However, the addition of ethanol in diesel fuel produces physicochemical changes and reduction in cetane number, viscosity, and flash point. Such changes influence the characteristics of the injected fuel jet and the quality of combustion and emissions (LI et al., 2005).

Biodiesel has been studied as a potential additive to improve the solubility of ethanol in diesel fuel, which could enhance its lubricity and mixing over a wide range of temperatures (RIBEIRO et al., 2007). Regarding the addition of ethanol in diesel fuel, Shadidi et al. (2014) state that $15 \%$ ethanol is the maximum addition without the need for mechanical modifications of the engine.

Some countries already sell mixtures of ethanoldiesel (ED) as fuel. In Thailand, 10\% ethanol is used in diesel oil, while in Australia, Sweden, and the United States, $15 \%$ ethanol mixtures are used (HANSEN et al., 2005).

Research indicates that the use of ED mixtures modifies the performance of a diesel-cycle engine, resulting in variations in power, fuel consumption, thermal efficiency, emission, and temperature of gas pollutants (AJAV et al., 1999).

Emissions of $\mathrm{CO}$ and $\mathrm{CO}_{2}$ are related to the quality of combustion; incomplete combustion will lead to greater emissions of $\mathrm{CO}$, while complete combustion will lead to higher $\mathrm{CO}_{2}$ emissions (SAYIN, 2010). Emissions of pollutants from diesel engines depend directly on fuel consumption under different driving conditions (JANULEVICIUS et al., 2016; TSE et al., 2015).

According to Al-Farayedhi et al. (2004), when ED mixtures are used, the temperature of the exhaust gases is lower compared to that when using pure diesel oil, so the $\mathrm{NO}_{\mathrm{x}}$ emissions are reduced. According to the authors, this is explained by the lower temperature produced during the combustion 
of the ED mixture. Furthermore, ethanol has the potential to decrease the amount of PM emitted by the engine due to the greater presence of $\mathrm{O}_{2}$ (KASS et al., 2001).

This study aimed to assess the emissions of a diesel-cycle engine of an agricultural tractor that uses mixtures of diesel oil and hydrated ethanol. Diesel oil S500 (B5) and its mixture with 3\% (ED3), 6\% (ED6), 9\% (ED9), 12\% (ED12), and $15 \%$ (ED15) ethanol were used.

\section{Materials and Methods}

Fuels and blends used

Diesel oil S500 (B5) and hydrated ethanol from sugarcane were used. Their physicochemical properties are shown in Table 1. The mixtures used in ED were made where the experiment was conducted. The volumetric density measurements of the six fuels used (B5, ED3, ED6, ED9, ED12, and ED15) are 845, 844, 843, 840, 838, and 837 $\mathrm{g} \mathrm{L}^{-1}$, respectively, at $19.5^{\circ} \mathrm{C}$ of room temperature.

Table 1. Chemical and physical properties of fuels used in the experiment.

\begin{tabular}{lcc}
\hline & Diesel oil S500 (B5)* & Ethanol \\
\hline $\mathrm{pH}$ & - & $6.0-8.0$ \\
Fusion point - Freeze & $-40-6{ }^{\circ} \mathrm{C}$ & $-117^{\circ} \mathrm{C}$ \\
Initial boiling point and boiling $\mathrm{T}^{\mathrm{o}}$ range & $150-471^{\circ} \mathrm{C}$ & $77^{\circ} \mathrm{C}$ \\
Flash point & $38^{\circ} \mathrm{C}$ & $15{ }^{\circ} \mathrm{C}($ closed vessel) \\
Steam pressure & $0.4 \mathrm{kPa}$ at $40^{\circ} \mathrm{C}$ & $5.8 \mathrm{kPa}$ at $20^{\circ} \mathrm{C}$ \\
Specific mass & $0.820-0.865$ at $20^{\circ} \mathrm{C}$ & $0.800\left(\right.$ water at $\left.4{ }^{\circ} \mathrm{C}=1\right)$ \\
Auto-ignition $\mathrm{T}^{\mathrm{o}}$ & $\geq 225^{\circ} \mathrm{C}$ & $363^{\circ} \mathrm{C}$ \\
Decomposition $\mathrm{T}^{\mathrm{o}}$ & $400^{\circ} \mathrm{C}$ & - \\
Viscosity & $2.5 \times 10^{-5}-5 \times 10^{-5} \mathrm{~m}^{2} \mathrm{~s}^{1}$ at $40^{\circ} \mathrm{C}$ & $1.20 \times 10^{-3} \mathrm{P} . \mathrm{s}$ at $20^{\circ} \mathrm{C}$ \\
\hline
\end{tabular}

*With $5 \%$ of biodiesel.

\section{Research engine}

The experiment was conducted using a Massey Ferguson tractor, model MF 4291 (Massey Ferguson, Canoas, Brazil), equipped with a fourcylinder Perkins engine, model 1104A-44T, 4.4 L of displaced volume, powered on turbocharger with potency and maximum torque of $77.2 \mathrm{~kW}(105 \mathrm{CV})$ and $400 \mathrm{Nm}$, respectively, under the ISO TR 14396 standard, according to manufacturer information. The engine fuel injection pump is mechanical and rotary, Delphi's brand.

\section{Test method and procedure}

Before starting the assessments, the engine was heated for $20 \mathrm{~min}$. For this, the accelerator was positioned at maximum speed and, using an electric
EGGERS dynamometer, model PT 301 MES, a load to reduce engine rotation to rated speed was applied. In addition, at each change of fuel, the engine was left working under load, so that any previous fuel residue in the injection system was consumed. A schematic representation of the experiment is shown in Figure 1.

The measurements were performed every second for three minutes using the Saxon opacimeter, model Opacilyt 1030, and Saxon gas analyzer, model Infralyt ELD. Both devices are controlled through the MWIELD O1030 software. For analysis, only the last 60 seconds of the collected data were considered. In each mode of operation, values of $\mathrm{O}_{2}$ ( $\%$ vol.) were also obtained using the same gas analyzer described previously, in addition to obtaining the gas temperature $\left({ }^{\circ} \mathrm{C}\right)$ using a type $\mathrm{K}$ thermocouple. 
Figure 1. Schematic representation of the experiment: 1. electric dynamometer; 2. opacimeter; 3. gas analyzer; 4. thermocouple; 5. agricultural tractor (research engine); 6. software MWIELD 01030.

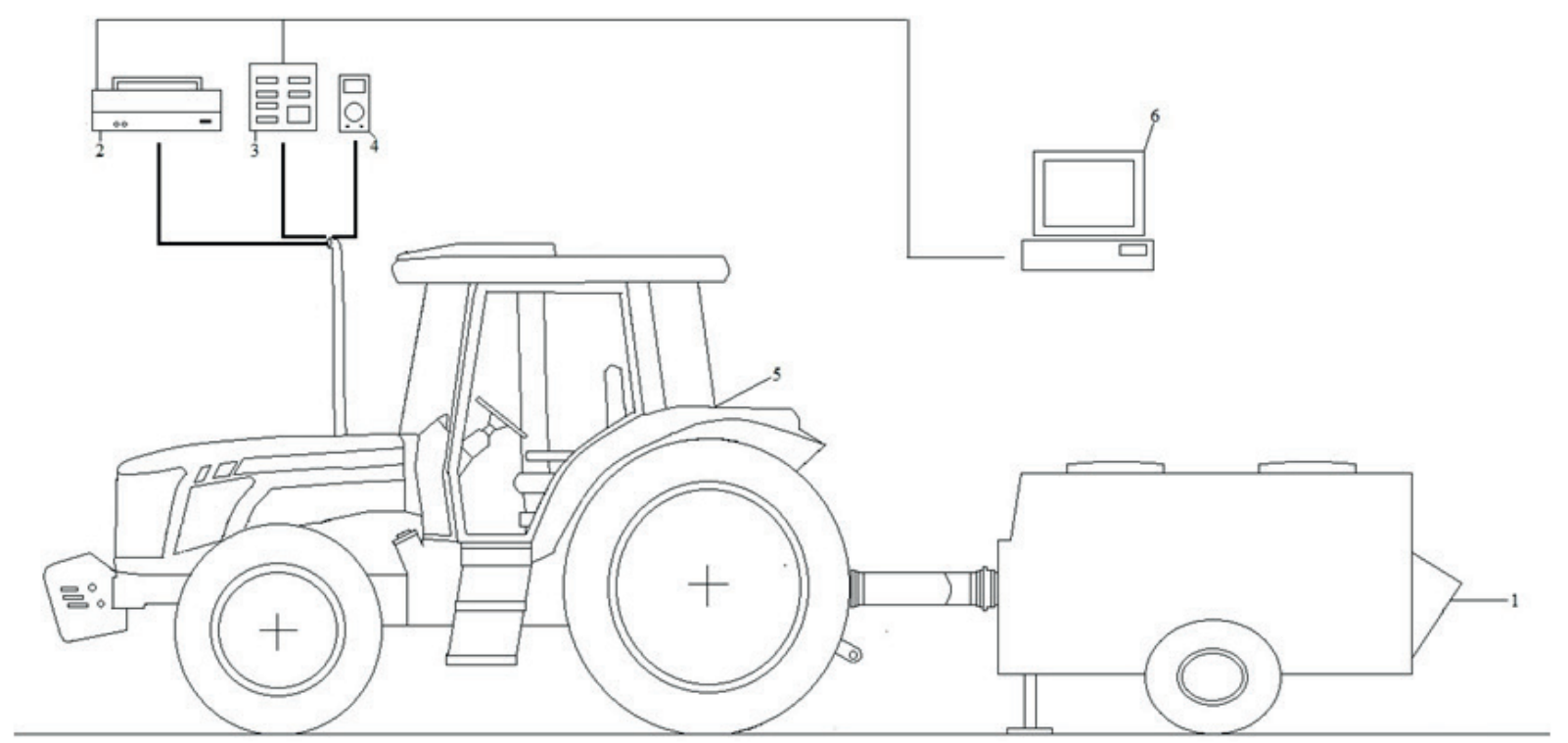

The measurements of opacity and emissions of gases from fuel combustion in the engine were $(10 \%)$ of the rated torque; three at the maximum based on the standard NBR ISO 8178-4 (ABNT, 2012), in which each emission experiment consists of eight operating modes (M1, M2, M3, M4, M5, M6, M7, and M8). The methods were determined as follows: four modes at rated speed, applying the loads M1 (100\%), M2 (75\%), M3 (50\%), and M4 torque speed, applying the loads M5 (100\%), M6 (75\%), and $\mathrm{M} 7$ (50\%) of rotation; and one (M8) at idling speed and without load (Figure 2). In each mode, opacity values of the gases were collected through the light absorption coefficient ( $\mathrm{k}$ value), $\mathrm{CO}_{2}$ (vol. \%), and $\mathrm{NO}_{\mathrm{x}}(\mathrm{ppm})$.

Figure 2. Test modes for Non-Road Steady Cycle: 1. engine torque curve; four loads applied at rated speed: M1 $(100 \%), \mathrm{M} 2(75 \%), \mathrm{M} 3(50 \%)$ and M4 (10\% of the rated torque; three loads applied at maximum torque speed: M5 (100\%), M6 (75\%) and M7 (50\% of the maximum torque); and one mode: without load (M8) at idling a speed.

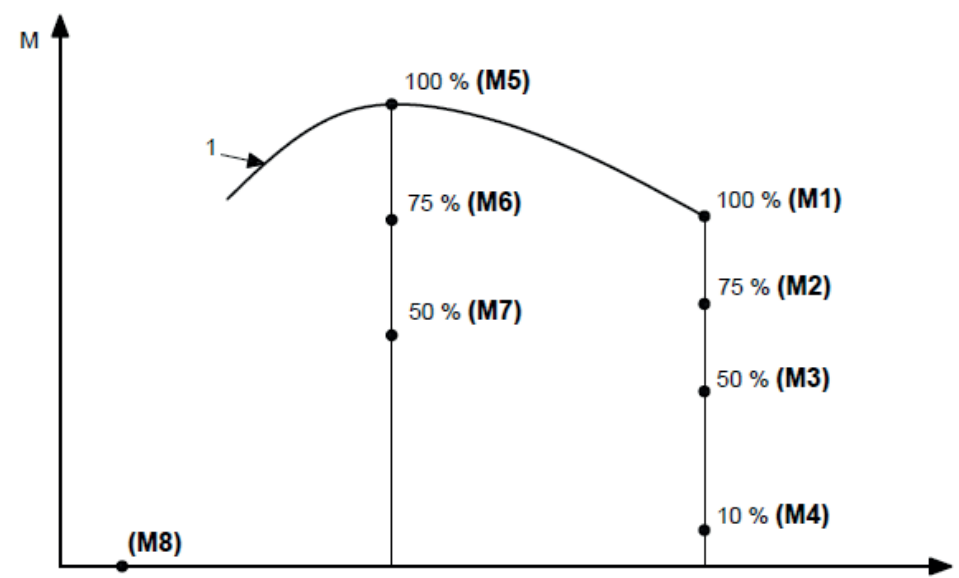

Source: ABNT NBR ISO 8178-4 (2012). 


\section{Experimental and statistical procedures}

The variables were analyzed according to a factorial scheme $(6 \times 8)$ from the interaction of the six types of fuel and the eight operating modes. Sixty repetitions were conducted, forming a completely randomized experimental design. Subsequently, using the Sisvar software, version 5.3 (FERREIRA, 2011), data were submitted to analysis of variance
(ANOVA), Tukey's test, at 5\% probability of error, and linear regression analysis.

\section{Results and Discussion}

According to the ANOVA results, there was a significant effect on the interaction between the two factors (F1: Types of fuel and F2: Operating modes) for all variables in this study (Table 2).

Table 2. Summary of the ANOVA for the opacity of the gases ( $\mathrm{k}$ value), carbon dioxide $\left(\mathrm{CO}_{2}\right)$ and nitrogen oxides $\left(\mathrm{NO}_{\mathrm{x}}\right)$ parameters.

\begin{tabular}{ccccc}
\hline \multirow{2}{*}{ Sources of variation } & \multirow{2}{*}{ Degrees of freedom } & \multicolumn{3}{c}{ Mean squares } \\
\cline { 3 - 5 } & & $\mathrm{k}$ value & $\mathrm{CO}_{2}$ & $\mathrm{NO}_{\mathrm{x}}$ \\
\hline $\mathrm{F} 1$ & 5 & 3.6 & 10.0 & 765550.5 \\
$\mathrm{~F} 2$ & 7 & 33.3 & 1786.0 & 88964549.4 \\
$\mathrm{~F} 1 \mathrm{x} \mathrm{F} 2 *$ & 35 & 1.5 & 1.5 & 102473.7 \\
Error & 2832 & 0.0 & 0.0 & 99.4 \\
CV $(\%)$ & & 5.61 & 0.27 & 1.20 \\
\hline
\end{tabular}

*There was a significant effect of the interaction between the factors $(\rho \leq 0.05)$.

Table 3 shows the results of the opacity of the gases and emissions of $\mathrm{CO}_{2}$ and $\mathrm{NO}_{\mathrm{x}}$ in each engine operating mode estimated for each fuel used. In general, it was observed that in the two analyzed rotations, as the load applied to the engine increases, the emissions also increase. In M5, when using ED3, ED6, and B5, pollutant emissions emitted by the engine were higher.

Table 4 shows the average opacity results, $\mathrm{CO}_{2}$, and $\mathrm{NO}_{x}$, considering the eight modes of engine operation, as well as the differences obtained using different mixtures to S500 diesel oil (B5).

\section{Opacity of the gases}

Regarding the opacity of the gases, the engine in $\mathrm{M} 1$ issued $0.31 \mathrm{~m}^{-1}$, using ED15, 18.42\% lower compared to B5. In operating modes M5, M6, and M7, lower opacity values were obtained using ED12 and ED15, with no statistical difference. Emission opacity can be reduced using ED mixture powered diesel-cycle engines, since the higher $\mathrm{O}_{2}$ content of the mixture causes a reduction in the formation of rich mixtures (LAPUERTA et al., 2008).

As shown in Table 4, the use of ED3 and ED6 resulted in higher opacity values compared to B5. According to the linear regression performed for this variable (Figure $3 \mathrm{~A}$ ), $71 \%$ of data are adjusted according to the equation, where the value of the opacity of the engine exhaust gas decreases $0.05 \mathrm{~m}^{-1}$ for each increment of $5 \%$ ethanol in B5, up to the mixture of $15 \%$. 
Table 3. Emissions of pollutants from the engine in the different modes of operation based on the standard NBR ISO 8178-4 (2012).

\begin{tabular}{|c|c|c|c|c|c|c|c|c|}
\hline \multirow{2}{*}{ Fuels } & \multicolumn{8}{|c|}{ Modes of operation } \\
\hline & M1 & M2 & M3 & M4 & M5 & M6 & M7 & M8 \\
\hline \multicolumn{9}{|c|}{ Opacity (k value) } \\
\hline B5 & $0.38^{\mathrm{b}}$ & $0.32^{\mathrm{b}}$ & $0.32 b^{c}$ & $0.27^{\mathrm{d}}$ & $1.40^{\mathrm{c}}$ & $0.49^{\mathrm{c}}$ & $0.48^{\mathrm{a}}$ & $0.24^{\mathrm{d}}$ \\
\hline ED3 & $0.42^{\mathrm{a}}$ & $0.34^{\mathrm{a}}$ & $0.34^{\mathrm{a}}$ & $0.31^{\mathrm{bc}}$ & $1.87^{\mathrm{a}}$ & $0.60^{\mathrm{a}}$ & $0.47^{\mathrm{a}}$ & $0.27^{\mathrm{bc}}$ \\
\hline ED6 & $0.38^{\mathrm{b}}$ & $0.32^{\mathrm{b}}$ & $0.32^{\mathrm{b}}$ & $0.32^{\mathrm{ab}}$ & $1.47^{\mathrm{b}}$ & $0.53^{\mathrm{b}}$ & $0.46^{\mathrm{b}}$ & $0.29^{\mathrm{a}}$ \\
\hline ED9 & $0.38^{\mathrm{b}}$ & $0.33^{\mathrm{a}}$ & $0.34^{\mathrm{a}}$ & $0.33^{\mathrm{a}}$ & $1.02^{\mathrm{d}}$ & $0.39^{\mathrm{d}}$ & $0.40^{\mathrm{c}}$ & $0.28^{\mathrm{ab}}$ \\
\hline ED12 & $0.36^{\mathrm{c}}$ & $0.31^{\mathrm{b}}$ & $0.32^{\mathrm{bc}}$ & $0.31^{\mathrm{bc}}$ & $0.70^{\mathrm{e}}$ & $0.32^{\mathrm{e}}$ & $0.34^{\mathrm{d}}$ & $0.26^{\mathrm{c}}$ \\
\hline ED15 & $0.31^{\mathrm{d}}$ & $0.29^{c}$ & $0.31^{\mathrm{c}}$ & $0.30^{\mathrm{c}}$ & $0.70^{\mathrm{e}}$ & $0.33^{\mathrm{e}}$ & $0.34^{\mathrm{d}}$ & $0.26^{\mathrm{c}}$ \\
\hline Mean & 0.37 & 0.32 & 0.32 & 0.31 & 1.19 & 0.44 & 0.42 & 0.27 \\
\hline CV (\%) & 9.24 & 4.82 & 3.48 & 6.42 & 39.10 & 25.83 & 14.93 & 7.61 \\
\hline \multicolumn{9}{|c|}{$\mathrm{CO}_{2}(\%$ vol. $)$} \\
\hline B5 & $7.35^{\mathrm{a}}$ & $6.08^{\mathrm{a}}$ & $5.33^{\mathrm{a}}$ & $3.03^{\mathrm{a}}$ & $8.20^{\mathrm{c}}$ & $6.78^{\mathrm{c}}$ & $5.43^{\mathrm{c}}$ & $1.32^{\mathrm{c}}$ \\
\hline ED3 & $7.35^{\mathrm{a}}$ & $6.08^{\mathrm{a}}$ & $4.89^{\mathrm{b}}$ & $3.02^{\mathrm{b}}$ & $8.64^{\mathrm{a}}$ & $7.00^{\mathrm{a}}$ & $5.56^{\mathrm{a}}$ & $1.31^{\mathrm{d}}$ \\
\hline ED6 & $7.27^{\mathrm{b}}$ & $6.02^{\mathrm{b}}$ & $4.85^{\mathrm{c}}$ & $3.02^{\mathrm{b}}$ & $8.30^{\mathrm{b}}$ & $6.96^{\mathrm{b}}$ & $5.52^{\mathrm{b}}$ & $1.32^{\mathrm{c}}$ \\
\hline ED9 & $7.10^{\mathrm{d}}$ & $5.90^{\mathrm{c}}$ & $4.74^{\mathrm{d}}$ & $2.97^{\mathrm{d}}$ & $7.85^{\mathrm{d}}$ & $6.66^{\mathrm{d}}$ & $5.32^{\mathrm{d}}$ & $1.31^{\mathrm{d}}$ \\
\hline ED12 & $7.12^{\mathrm{c}}$ & $5.85^{\mathrm{d}}$ & $4.65^{\mathrm{e}}$ & $2.95^{\mathrm{e}}$ & $7.62^{\mathrm{f}}$ & $6.51^{\mathrm{f}}$ & $5.24^{\mathrm{f}}$ & $1.38^{\mathrm{b}}$ \\
\hline ED15 & $6.81^{\mathrm{e}}$ & $5.75^{\mathrm{e}}$ & $4.64^{\mathrm{f}}$ & $2.98^{\mathrm{c}}$ & $7.71^{\mathrm{e}}$ & $6.62^{\mathrm{e}}$ & $5.30^{\mathrm{e}}$ & $1.45^{\mathrm{a}}$ \\
\hline Mean & 7.17 & 5.95 & 4.85 & 3.00 & 8.05 & 6.75 & 5.40 & 1.35 \\
\hline CV (\%) & 2.84 & 2.27 & 5.27 & 1.18 & 4.85 & 2.88 & 2.36 & 4.41 \\
\hline \multicolumn{9}{|c|}{$\mathrm{NO}_{\mathrm{x}}(\mathrm{ppm})$} \\
\hline B5 & $1255.05^{\mathrm{c}}$ & $903.43^{\mathrm{c}}$ & $610.25^{\mathrm{a}}$ & $165.67 b^{c}$ & $1523.17^{b}$ & $1336.88^{b}$ & $767.50^{c}$ & $262.60^{\mathrm{d}}$ \\
\hline ED3 & $1272.75^{\mathrm{b}}$ & $935.38^{\mathrm{a}}$ & $517.63^{\mathrm{b}}$ & $170.15^{\mathrm{ab}}$ & $1477.82^{\mathrm{d}}$ & $1396.90^{\mathrm{a}}$ & $894.20^{\mathrm{a}}$ & $275.10^{\mathrm{b}}$ \\
\hline ED6 & $1286.75^{\mathrm{a}}$ & $926.73^{b}$ & $502.50^{\mathrm{c}}$ & $171.65^{\mathrm{a}}$ & $1536.57^{\mathrm{a}}$ & $1394.62^{\mathrm{a}}$ & $837.68^{\mathrm{b}}$ & $271.78^{\mathrm{bc}}$ \\
\hline ED9 & $1258.23^{\mathrm{c}}$ & $891.53^{\mathrm{d}}$ & $479.95^{\mathrm{d}}$ & $163.60^{\mathrm{cd}}$ & $1495.63^{\mathrm{c}}$ & $1312.67^{\mathrm{c}}$ & $709.27^{\mathrm{d}}$ & $258.63^{\mathrm{d}}$ \\
\hline ED12 & $1219.18^{\mathrm{d}}$ & $856.27^{\mathrm{e}}$ & $454.07^{\mathrm{e}}$ & $159.73^{\mathrm{de}}$ & $1477.13^{\mathrm{d}}$ & $1271.27^{\mathrm{d}}$ & $644.90^{\mathrm{f}}$ & $292.33^{\mathrm{a}}$ \\
\hline ED15 & $1127.45^{\mathrm{e}}$ & $778.38^{\mathrm{f}}$ & $432.90^{\mathrm{f}}$ & $156.55^{\mathrm{e}}$ & $1473.75^{\mathrm{d}}$ & $1250.22^{\mathrm{e}}$ & $673.20^{\mathrm{e}}$ & $269.68^{c}$ \\
\hline Mean & 1236.57 & 881.96 & 499.55 & 164.56 & 1497.34 & 1327.09 & 754.48 & 271.69 \\
\hline CV (\%) & 4.69 & 6.57 & 12.50 & 3.56 & 1.78 & 4.62 & 12.89 & 4.34 \\
\hline
\end{tabular}

*Means followed by the same letter in the column do not differ by the Tukey test at $5 \%$ error probability.

Table 4. Average values of the engine pollutant emissions for the mixtures used and their variations $(\Delta \%)$, in relation to the diesel oil S500 (B5).

\begin{tabular}{ccccccc}
\hline Fuels & Opacity $(\mathrm{k} \text { value })^{*}$ & $\Delta(\%)$ & $\mathrm{CO}_{2}(\%$ vol. $)$ & $\Delta(\%)$ & $\mathrm{NO}_{\mathrm{x}}(\mathrm{ppm})$ & $\Delta(\%)$ \\
\hline B5 & $0.49^{\mathrm{c}}$ & 0.00 & $5.44^{\mathrm{b}}$ & 0.00 & $853.07^{\mathrm{b}}$ & 0.00 \\
ED3 & $0.58^{\mathrm{a}}$ & 18.37 & $5.48^{\mathrm{a}}$ & 0.74 & $867.49^{\mathrm{a}}$ & 1.69 \\
ED6 & $0.51^{\mathrm{b}}$ & 4.08 & $5.41^{\mathrm{c}}$ & -0.55 & $866.04^{\mathrm{a}}$ & 1.52 \\
ED9 & $0.44^{\mathrm{d}}$ & -10.20 & $5.23^{\mathrm{d}}$ & -3.86 & $821.19^{\mathrm{c}}$ & -3.74 \\
ED12 & $0.37^{\mathrm{e}}$ & -24.49 & $5.17^{\mathrm{e}}$ & -4.96 & $796.86^{\mathrm{d}}$ & -6.59 \\
ED15 & $0.36^{\mathrm{f}}$ & -26.53 & $5.16^{\mathrm{f}}$ & -5.15 & $770.28^{\mathrm{e}}$ & -9.70 \\
\hline
\end{tabular}

* Means followed by the same letter in the column do not differ by the Tukey test at $5 \%$ error probability. 
The highest opacity values coincide with the highest average temperatures of the gases (Figure 4A). Using ED3, ED6, and B5, temperatures of 291.50, 291.31, and $288.00{ }^{\circ} \mathrm{C}$, respectively, were achieved. The same tendency was observed when using ED9, ED12, and ED15, for which the lowest gas temperature values were found.

Figure 3. Average emissions of engine pollutants as a function of the ethanol content in the $\mathrm{B} 5$ (0): opacity (a); $\mathrm{CO}_{2}$ (b) and $\mathrm{NO}_{\mathrm{x}}$ (c).
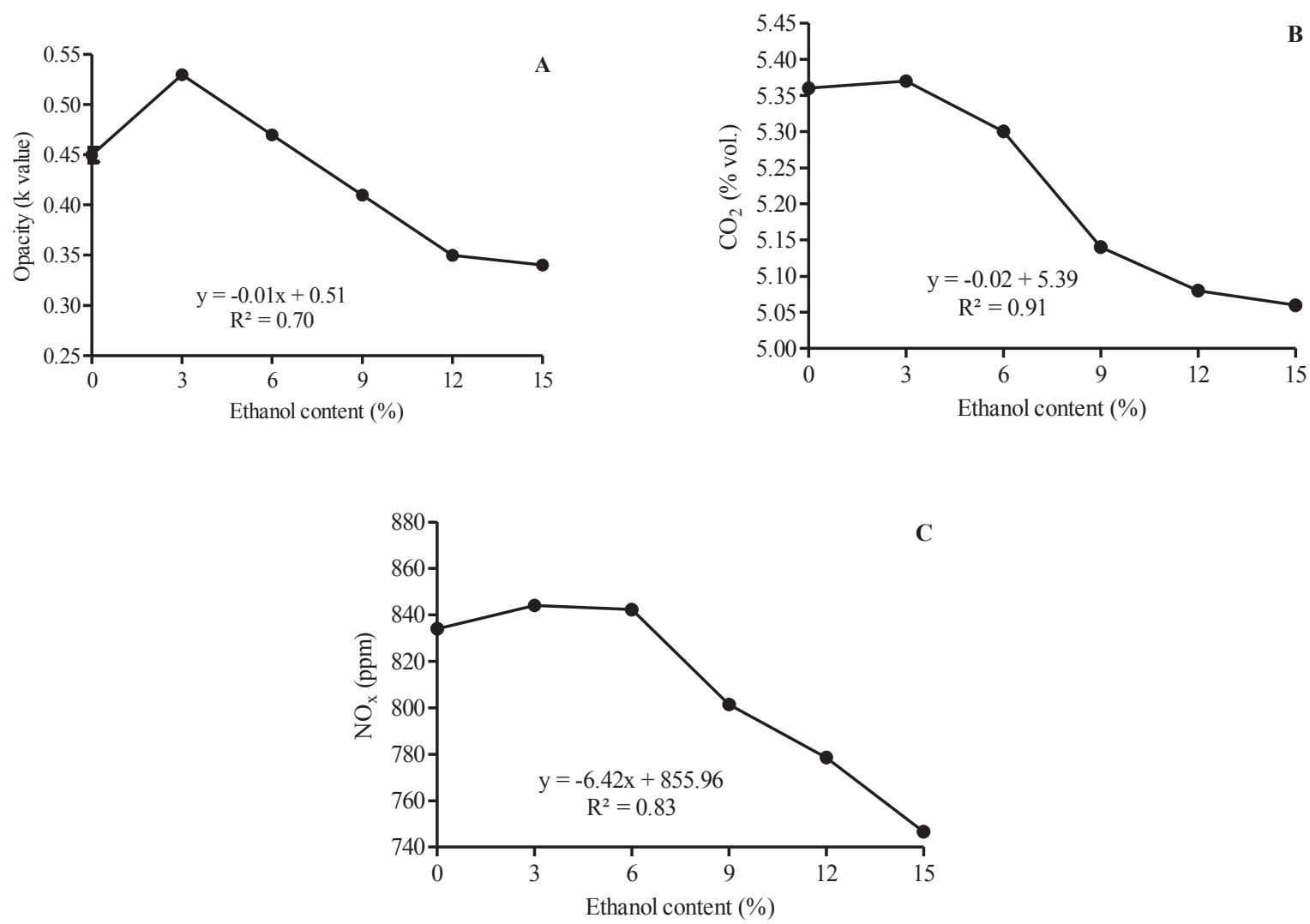

Figure 4. Exhaust gases temperature (a) and $\mathrm{O}_{2}$ (b) emitted by the engine as a function of the ethanol content in the B5 (0).
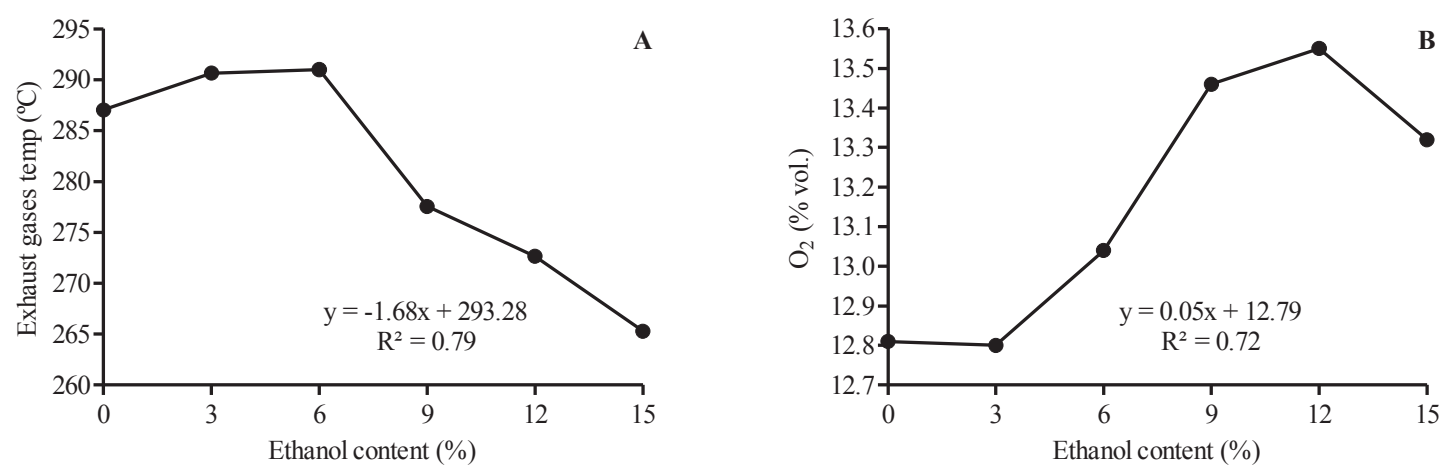
Similar results were found by Ahmed (2001) and Armas et al. (2012), obtaining a reduction of 17 to $20 \%$ in the opacity of the gases using ED10 compared to diesel oil. Ahmed (2001) achieved a reduction of $24 \%$ with ED15.

\section{Emissions of $\mathrm{CO}_{2}$}

Considering the variable $\mathrm{CO}_{2}$, the highest values were obtained in M5. In this mode, using ED9, ED12, and ED15, $\mathrm{CO}_{2}$ emissions were 4.27, 7.07, and $5.98 \%$, respectively, lower than B5. In M1, M2, and $\mathrm{M} 3, \mathrm{CO}_{2}$ emission with ED15 had a reduction of $7.34,5.42$, and $12.95 \%$, respectively, compared to B5. According to Usta et al. (2005), oxygenated fuels promote reduction of $\mathrm{CO}_{2}$ during combustion, with a rich mixture and with the engine running at full load.

Further, regarding the variable $\mathrm{CO}_{2}$, the highest values were obtained using ED3, B5, and ED6. From the linear regression of the data (Figure 3B), the adjustment equation indicates that to every $5 \%$ ethanol added to diesel oil, $\mathrm{CO}_{2}$ emissions decrease by $1 \%$ vol.

An inverse tendency was observed between $\mathrm{CO}_{2}$ and $\mathrm{O}_{2}$ (Figure 4B), as for fuels ED3, B5, and ED6, the lowest values of $\mathrm{O}_{2}$ were obtained: $12.63,12.69$, and $12.88 \%$ vol., respectively. With ED9, ED12, and ED15, $\mathrm{CO}_{2}$ emissions were reduced compared to $\mathrm{B} 5$, while $\mathrm{O}_{2}$ levels increased, reaching $13.44 \%$ vol. using ED12.

Similar studies reported that the addition of high amounts of ethanol in diesel fuel decreases $\mathrm{CO}_{2}$ emissions during combustion (CHAUHAN et al., 2011). Using ED10, Guarieiro et al. (2009) obtained a $6 \%$ reduction in $\mathrm{CO}_{2}$ emissions compared with the use of mineral diesel oil. Rodríguez (2003) obtained a reduction of $8 \%$ in $\mathrm{CO}_{2}$ emissions with the same mixture.

\section{Emissions of $\mathrm{NO}_{x}$}

Using ED15 in M1, $\mathrm{NO}_{\mathrm{x}}$ emission was reduced by $10.17 \%$ compared to B5 (Table 3 ). In M2, M3, and M4, with ED15, the reductions were 13.84, 29.06 , and $5.50 \%$, respectively. At the maximum torque rotation, in $\mathrm{M} 5, \mathrm{M} 6$, and $\mathrm{M} 7$, the lowest $\mathrm{NO}_{\mathrm{x}}$ emissions were found with the ED15 mixture, with a reduction of $3.24,6.48$, and $12.27 \%$, respectively, compared to B5.

The highest average $\mathrm{NO}_{\mathrm{x}}$ emissions (Figure 3C) was found when the engine used ED3 and ED6, and even the highest average temperature of the exhaust gases was obtained with the same mixtures (Figure 4A). $\mathrm{NO}_{\mathrm{x}}$ reductions of $3.74,6.59$, and $9.70 \%$ were obtained, respectively, in relation to B5 with mixtures ED9, ED12, and ED15.

According to Ahmed (2001), with ED10 and ED15 fuels, it was possible to reduce $\mathrm{NO}_{\mathrm{x}}$ emission by 4 and 5\%, respectively, compared with diesel oil. Song et al. (2010), working with ED15, obtained a $7.79 \%$ reduction in $\mathrm{NO}_{\mathrm{x}}$. Hansen et al. (2006) and Ren et al. (2008), using ED mixtures, found that due to the higher heat of evaporation of the mixture, $\mathrm{NO}_{\mathrm{x}}$ emissions could be reduced, and concluded that ethanol can effectively reduce the emission of this pollutant.

\section{Conclusions}

The mixture of hydrous ethanol in diesel oil S500, especially mixtures with over $6 \%$ ethanol, can be used as an alternative fuel for agricultural tractor engines in order to reduce the average values of $\mathrm{CO}_{2}$ and $\mathrm{NO}_{\mathrm{x}}$ emissions, as well as the opacity of the diesel-cycle engine gases.

\section{References}

AGEJAS, L. A. Biocombustibles: utilización de los aceites vegetales como energía renovable. Madrid: Ministerio de Agricultura, Pesca y Alimentación, 1996. $203 \mathrm{p}$. 
AHMED, I. Oxygenated diesel: emissions and performance characteristics of ethanol/Diesel blends in CI engines. Costa Mesa: SAE Technical Paper 2001-012475, 2001. 8 p.

AJAV, E. A.; SINGH, B.; BHATTACHARYA, T. K. Experimental study of some performance parameters of a constant speed stationary Diesel engine using ethanolDiesel blends as fuel. Biomass Bioenergy, Manchester, v. 17, n. 4, p. 357-365, 1999.

AL-FARAYEDHI, A. A.; AL-DAWOOD, A. M.; GANDHIDASAN, P. Experimental investigation of SI engine performance using oxygenated fuel. Journal of Engineering for Gas Turbines and Power, New York, v. 126, n. 1, p. 178-191, 2004.

AL-HASSAN, M.; MUJAFET, H.; AL-SHANNAG, M. An experimental study on the solubility of a Dieselethanol and on the performance of a diesel engine fueled with diesel-biodiesel-ethanol-blends. Jordan Journal of Mechanical and Industrial Engineering, Jordan, v. 6, n. 2, p. 147-153, 2012.

ARMAS, O.; GARCIA-CONTRERAS, R.; RAMOS, A. Pollutant emissions from engine starting with ethanol and butanol Diesel blends. Fuel Processing Technology, Groningen, v. 100, n. 1, p. 63-72, aug. 2012.

ASSOCIAÇÃO BRASILEIRA DE NORMAS TÉCNICAS - ABNT. NBR ISO 8178-4: motores alternativos de combustão interna - medição da emissão de gases de exaustão. Parte 4: ciclos de ensaio em regime constante para diferentes aplicações de motor. Rio de Janeiro: Editora ABNT, 2012.

CHAUHAN, B. S.; KUMAR, N.; PAL, S. S.; JUN, Y. D. Experimental studies on fumigation of ethanol in small capacity Diesel engine. Energy, Londres, v. 36, n. 2, p. 1030-1038, 2011.

FERREIRA, D. F. Sisvar: a computer statistical analysis system. Ciência e Agrotecnologia, Lavras, v. 35, n. 6, p. 1039-1042, 2011.

GENG, P.; CAO, E.; TAN, Q.; WEI, L. Effects of alternative fuels on the combustion characteristics and emission products from diesel engines: A review. Renewable and Sustainable Energy Reviews, Amsterdam, v. 71, n. 1, p. 523-534, 2017.

GIAKOUMIS, E. G.; RAKOPOULOS, C. D.; DIMARATOS, A. M.; RAKOPOULOS, D. C. Exhaust emissions with ethanol or n-butanol Diesel fuel blends during transient operation: a review. Renewable and Sustainable Energy Reviews, Amsterdam, v. 17, n. 1, p. 170-190, 2013.

GUARIEIRO, L. L. N.; SOUZA, A. F.; TORRES, E. A.; ANDRADE, J. B. Emission profile of 18 carbonyl compounds, $\mathrm{CO}, \mathrm{CO} 2$, and $\mathrm{NOx}$ emitted by a diesel engine fuelled with diesel and ternary blends containing diesel, ethanol and biodiesel or vegetable oils. Atmospheric Environment, Amsterdam, v. 43, n. 17, p. 2754-2761, 2009.

HANSEN, A. C.; GRATTON, M. R.; YUAN, W. Diesel engine performance and NOx emissions from oxygenated biofuels and blends with Diesel fuel. ASABE, St. Joseph, v. 49, n. 3, p. 589-595, 2006.

HANSEN, A. C.; ZHANG, Q.; LYNE, P. W. L. Ethanoldiesel fuel blends: a review. Bioresource Technology, Amsterdam, v. 96, n. 3, p. 277-285, 2005.

JANULEVICIUS, A.; JUOSTAS, A.; CIPLIEN, A. Estimation of carbon-oxide emissions of tractors during operation and correlation with the not-toexceed zone. Biosystems Engineering, Auburn, v. 147, n. 1, p. 117129, 2016.

KASS, M.; THOMAS, J.; STOREY, J.; DOMINGO, N.; WADE, J.; KENRECK, G. Emissions from of 5.9 liter Diesel engine fueled with ethanol Diesel blends. Heidelberg: SAE Technical Paper 2001-01-2018, 2001. $9 \mathrm{p}$.

KIM, Y. S.; HAN, E. J.; SOHN, S. T. Demand forecasting for heavy-duty diesel engines considering emission regulations. Sustainability, Basel, v. 9, n. 2, p. 1-16, 2017.

LAPUERTA, M.; ARMAS, O.; HERREROS, J. M. Emissions from a Diesel-bioethanol blend in an automotive Diesel engine. Fuel, Amsterdam, v. 87, n. 1, p. 25-31, 2008.

LEVY, R. J. Carbon monoxide pollution and neurodevelopment: a public health concern. Neurotoxicology Teratology, Amsterdam, v. 49, n. 1, p. 31-40, 2015.

LI, D.; ZHEN, H.; XINGCAI, L.; WU-GAO, Z.; JIANHUANG, Y. Physico-chemical properties of ethanolDiesel blend fuel and its effect on performance and emissions of Diesel engines. Renewable Energy, Londres, v. 30, n. 6, p. 967-976, 2005.

MANZETTI, S.; ANDERSEN, O. Biochemical and physiological effects from exhaust emissions: a review of the relevant literature. Pathophysiology, Amsterdam, v. 23, n. 4 , p. 285-293, 2016.

MOFIJUR, M.; RASUL, M. G.; HYDE, J. Recent developments on internal combustion engine performance and emissions fuelled with biodiesel-dieselethanol blends. Procedia Engineering, Londres, v. 105, n. 1, p. 658-664, 2015.

REN, Y.; HUANG, Z. H.; JIANG, D. M.; LI, W.; LIU, B.; WANG, X. B. Effect of the addition of ethanol and 
cetane number improver on the combustion and emission characteristics of a compression ignition engine. Journal of Automobile Engineering, Londres, v. 222, n. 6, p. 1077-1087, 2008.

RESITOGLU, I. A.; KESKIN, A. Hydrogen applications in selective catalytic reduction of $\mathrm{NO}_{\mathrm{x}}$ emissions from diesel engines. International Journal of Hydrogen Energy, Londres, v. 42, n. 36, p. 1-6, 2017.

RIBEIRO, N. M.; PINTO, A. C.; QUINTELLA, C. M.; ROCHA, G. O.; TEIXEIRA, L. S. G.; GUARIEIRO, L. L. N.; RANGEL, M. C.; VELOSO, M. C. C.; REZENDE, M. J. C.; CRUZ, R. S.; OLIVEIRA, A. M.; TORRES, E. A.; ANDRADE, J. B. The role of additives for Diesel and Diesel blended (ethanol or biodiesel) fuels: A review. Energy \& Fuels, New York, v. 21, n. 4, p. 2433-2445, 2007.

RODRÍGUEZ, J. C. Life cycle assessment of woodbased ethanol-diesel blends (E-Diesel). 2003. Master (International Master of Environmentally Sustainable Process Technology) - Chalmers University of Technology, Stenungsund.

SAYIN, C. Engine performance and exhaust gas emissions of methanol and ethanol-Diesel blends. Fuel, Amsterdam, v. 89, n. 11, p. 3410-3415, 2010.

SHADIDI, B.; YUSAF, T.; ALIZADEH, H. H. A.; GHOBADIAN, B. Experimental investigation of the tractor engine performance using diesohol. Applied Energy, Londres, v. 114, n. 1, p. 874-879, feb. 2014.

SONG, C.; ZHAO, Z.; LV, G.; SONG, J.; LIU, L.; ZHAO, R. Carbonyl compound emissions from a heavyduty Diesel engine fueled with Diesel fuel and ethanolDiesel blend. Chemosphere, Oxford, v. 79, n. 11, p. 10331039, 2010.

TADANO, Y. S.; BORILLO, G. C.; GODOI, A. F. L.; CICHON, A.; SILVA, T. O. B.; VALEBONA, F. B.; ERRERA, M. R.; PENTEADO NETO, R. A.; REMPEL, D.; MARTIN, L.; YAMAMOTO, C. I.; GODOI, R. H. M. Gaseous emissions from a heavy-duty engine equipped with SCR after treatment system and fuelled with Diesel and biodiesel: assessment of pollutant dispersion and health risk. Science of The Total Environment, Amsterdam, v. 500-501, n. 1, p. 64-71, 2014.

TSE, H.; LEUNG, C. W.; CHEUNG, C. S. Investigation on the combustion characteristics and particulate emissions from a diesel engine fueled with dieselbiodiesel-ethanol blends. Energy, Londres, v. 83, n. 1, p. 343-350, 2015.

USTA, N.; OZTURK, E.; CAN, O.; CONKUR, E. S.; NAS, S.; ÇON, A. H.; CAN, A. Ç.; TOPCU, M. Combustion of biodiesel fuel produced from hazelnut soap stock/waste sunflower oil mixture in a Diesel engine. Energy Conversion \& Management, Nottingham, v. 46, n. 5, p. 741-755, 2005. 